\title{
Staged Glory: The Impact of Fascism on 'Cooperative' Nationalist Circles in Late Colonial Indonesia, $1935^{-1942}$
}

\author{
Yannick Lengkeek \\ Leiden University \\ y.lengkeek@umail.leidenuniv.nl
}

\begin{abstract}
This article examines the circulation and articulation of fascist ideas and practices among the so-called cooperating nationalist party Partai Indonesia Raya (Parindra) and its youth wing Surya Wirawan in late colonial Indonesia. After the radical nationalist parties demanding Indonesian independence had been crushed by the Dutch colonial government in 1934, only parties refraining from making such radical demands could operate in public. Since their frustratingly weak bargaining position in the political arena was hard to conceal, leading Parindra politicians such as Soetomo (1888-1938) evoked powerful images of a 'glorious Indonesia' (Indonesia Moelia) to keep the nationalist project alive. The ideas of Soetomo, who was an expressed admirer of Mussolini, Hitler, and Japanese imperialism, had a considerable impact on Parindra's political course. Others, such as the journalist Soedarjo Tjokrosisworo were particularly vocal about their fascist sympathies. Tjokrosisworo played an influential role in modelling the 'scout group' on the example of fascist fighting squads and other paramilitary units. The article argues that Parindra's philofascist demeanor was an integral part of a strategy to achieve an aura of power. However, the party's dynamism and glory was just 'staged' to compensate for Parindra's lacking scope of political action. Generally, the party's incorporation of fascist elements raises important questions about the relationship between anticolonial nationalism and fascism since the latter entered Indonesia during a time when the nationalist project was still very much in the making.
\end{abstract}

\section{Keywords}

fascism-anticolonial nationalism-Indonesia-decolonization-scouting-modernity

(C) LENGKEEK, 2018 | DOI 10.1163/22116257-00701003

This is an open access article distributed under the terms of the prevailing CC-BY-NC License at the time of publication. 
On 21 April 1933, shortly after Hitler's successful seizure of power in Germany, an anonymous author with the pen name Marhaen Melarat (loosely translated: impoverished common man) published an article entitled 'The Independence Movement and the Current of Fascism' in which he concluded:

There were events in the [recent] past during which the Peoples' Movement faced a number of obstacles caused by various reactions which did not differ [from obstacles communists encountered in European countries]. Said obstacles were caused by the inclusion of suggestions from fascist circles. Among the people of Indonesia, the current of fascism has started to spread as well, and when it spreads unseen, it can also become dangerous for the Marhaen class. ${ }^{1}$

This early sensitivity for fascism was widespread among Indonesians with socialist leanings, for they were painfully aware of fascism's potential to absorb the populist appeal of their movement into an aggressive form of ultra-nationalism.

Fascism's ultimate inability to take deep roots in late colonial Indonesian society can appear 'self-evident' in hindsight, especially vis-à-vis the booming success of communist ideas. After Indonesia's 'national awakening' took ground in the 1910s, Indonesian nationalism in the 1920s was spearheaded by the openly anticolonial Partai Komunis Indonesia [PKI; Indonesian Communist Party] until that party was crushed by the Dutch colonial authorities in 1927-28. In the same turbulent year, Sukarno, who was to become Indonesia's first President after the proclamation of independence in 1945, founded the Partai Nasional Indonesia [PNI; Indonesian National Party]. Known for his charisma and his fiery oratory, he posed a great threat to Dutch colonial rule in the Indonesian archipelago, as his movement gained momentum on an unprecedented scale. Hence, he was finally arrested in 1929, only to be released from prison and then rearrested in 1933, when he was finally sent into internal exile first in Flores and then in Bengkulu (Southwest Sumatra). Sukarno's ideas drew heavily from Marxist thought, and he synthesized them into an eclectic ideology often named Marhaenism, an eponym inspired by the alleged encounter between Sukarno and a Javanese peasant called Marhaen. ${ }^{2}$ In his speeches and

1 Fikiran Ra'jat 41-42, April 21, 1933, 11.

2 A detailed anglophone analysis of Marhaenism has not been written yet, despite the concept's prominence in Indonesian political debates. Originally a Sundanese word meaning 'small farmer', the word was popularized by the Islamic organization Sarekat Islam in the 1910s and early 1920s. In the late 1920s, Sukarno adopted the word as an important component of his 
publications, Sukarno relentlessly promoted this neologism meant to describe the common Indonesian man of humble origins, as can be seen in the opening quote taken from Fikiran Rajat [People's Thought], a journal he published throughout the year 1933 until he was sent into exile. Even when Sukarno's ideas were forced to go 'underground,' as the colonial authorities drastically tightened their grip on the nationalist movement, concepts borrowed from communism remained a mainstay of Indonesian nationalist thought until the colony was finally occupied by the Japanese in March 1942. Why was this socialist influence so visible in the historiography on Indonesia, while fascism barely makes an appearance?

As Robert Cribb put it, merely promoting the revitalisation of traditional Indonesian political forms was too unspecific a goal to form a significant part of the nationalist critique of colonial rule; Indonesia could have no Phan Boi Chao [an important pioneer of Vietnamese nationalism], no Meiji Emperor. The Marxist critique, by contrast, was not only powerful but unambiguously modern. ${ }^{3}$ However, as I shall show during the course of my argument, fascism's promise of a flawless synthesis between 'modernity' and 'tradition' found influential admirers in Indonesia, and socialists, as well as communists, were among the first to detect that influence. In fact, their own struggle for a united and communist Indonesia forced them to adapt their modernist message to local cultural and social imperatives,' too. ${ }^{4}$ Hence, the allure of fascism can and should be placed alongside communism, Islamic modernism, moderate nationalism and many other political paths as part of a - so far neglected critical engagement by Indonesians with Western views on societal issues and nationhood. ${ }^{5}$ In short: Anticolonial nationalism took on many forms, and it is only in hindsight that we can say that fascism, at least in the sense of an organized mass movement, was just a 'flash in the pan'. Yet, as Frederick Cooper succinctly put it while discussing potential flaws in historical writing, it is

own, distinct nationalist vocabulary. On the genesis and role of Marhaenism under Sukarno, see John Ingleson, Road to Exile: The Indonesian Nationalist Movement 1927-1934 (Singapore: Heinemann Educational Books, 1979), 190-192; for a more detailed study of Marheanism's roots in Marxism and socialism, I refer to Ign. Gatut Saksono, Marhaenisme Bung Karno: Marxisme ala Indonesia (Yogyakarta: Rumah Belajar Yabinkas, 2007).

3 Robert Cribb, 'The Indonesian Marxist Tradition,' in Marxism in Asia, ed. Colin Mackerras and Nick Knight (Kent: Croom Helm, 1985), 257.

4 R.E. Elson, 'Indonesia and the West: An Ambivalent, Misunderstood Engagement,' Australian Journal of Politics and History 52, no. 2 (2006): 264.

5 Elson, 'Indonesia and the West,' 264. 
crucial to look at 'what one does not see: the paths not taken, the dead ends of historical processes, the alternatives that appeared to people in their times. ${ }^{6}$

I argue that fascism was seriously contemplated as such an 'alternative' by Indonesian nationalists whose sympathies did not lie with socialism. That being said, fascism was more of a practical than an intellectual influence, a point that has been entirely missed in studies of illiberal and authoritarian trends in Indonesia. David Bourchier, whose recent publication Illiberal Democracy in Indonesia made a valuable contribution to debates about the historical roots of the ideology of the 'family state' in Indonesia, remarks that it is hard to gauge ' $[\mathrm{h}]$ ow far conservative Indonesian nationalist thought was influenced by more explicitly fascist or National Socialist ideologies. ${ }^{7}$ From the viewpoint of intellectual history, this remark certainly holds true, since a cohesive body of thought based on fascist references never emerged in Indonesia. However, 'nationalist thought' goes well beyond intellectual constructions of culture, race, or ideals of statehood. Fundamental elements such as organizational principles (e.g., the fascist ideal of the 'cadre' or 'squad') and sets of values (e.g., militarism) are essential building blocks of any political movement, and it is in this realm of performative politics and mass-mobilization that historians can detect a strong fascist imprint. Intellectual history alone will not get us very far in this department. In this article, I look at the history of Partai Indonesia Raya [Parindra; Great Indonesia Party], one of the largest Indonesian political parties in the late 1930s, asking the following question: what did anticolonial nationalism in Indonesia during the late 1930s and early 1940s do with fascism? And what did fascism do with 'mainstream' nationalism?

The room for maneuver was claustrophobic as far as hands-on political action was concerned. I argue that Parindra's obsession with cadre-forming, unity, and glory was as much a preparation for better times as it was a compensation mechanism to push through this period of hardship. The creed guiding Parindra's development can be summarized with the popular slogan 'fake it till you make it,' and the national glory advocated by leading Parindra politicians referred both to a means (the performance of glory based on fascist ideals) and an end - a 'glorious Indonesia' (Indonesia Moelia). As this article attempts to show, fascism was a key influence in this process of 'staging glory.'

6 Frederick Cooper, Colonialism in Question: Theory, Knowledge, History (Berkeley: University of California Press, 2005), 18.

7 David Bourchier, Illiberal Democracy in Indonesia: The Ideology of the Family State (London: Routledge, 2015), 31. 


\section{Fascism in Indonesia: Approaching a Lacuna}

Apart from a single Indonesian publication entitled Orang dan Partai Nazi di Indonesia [Nazis and Nazi Parties in Indonesia], dealing - although only in part - with fascist tendencies in late colonial Indonesia, ${ }^{8}$ historians have consistently ignored the question whether there was any profound interplay between fascism and certain strands of anticolonial nationalism. While the aforementioned monograph was unquestionably a breath of fresh air pointing out a domain for further research, it did not attempt a systematic analysis of fascist influences. Focusing too much on the isolated case of a self-proclaimed 'fascist party' in 1933 that barely outlasted its own announcement in the Dutch and Indonesian press, the author does not investigate other, more striking 'oddities' he encountered during his research, such as the use of the Nazi salute among the youth organization of Parindra. This is particularly puzzling since he uses a photo of such a salute scene as the cover of his book. Yet, not a single paragraph is dedicated to an analysis of this youth organization and the question whether this salute was just a one-time event, or the performative manifestation of ideas that had a solid footing among the party's membership.

I can only speculate on the reasons why fascism, both as a term and a concept, has been widely avoided in debates about nationalism in Indonesia despite the fact that scholars like Susan Abeyasekere, who has written the most important study of Parindra up to this day, looked at a part of the relevant source material as early as the 1960 s and $1970 .^{9}$ While she never mentions the Nazi salute used by Parindra's youth organization or the expressions of sympathy for the Axis powers among the party's upper echelons, the sources she quotes indicate that she must have looked at some of the material this article is based on. I suspect that 'fascism', both as a term and a concept, had no established use for the investigation of anticolonial nationalist movements during the time Abeyasekere published her work on Parindra.

As matters stand now, fascism in Indonesia is usually associated with the Indonesian branch of the Nationaal-Socialistische Beweging [NSB; National Socialist Movement], whose entire membership was either Dutch or of mixed

8 Wilson, Orang dan Partai Nazi di Indonesia: Kaum Pergerakan Menyambut Fasisme (Depok: Komunitas Bambu, 2008).

9 Susan Abeyasekere, Relations between the Indonesian Cooperating Nationalists and the Dutch, 1935-1942 (PhD diss., University of Adelaide, 1972); a condensed version of central arguments in this publication, with an explicit focus on Parindra, is presented in Susan Abeyasekere, 'Partai Indonesia Raya, 1936-42: A Study in Cooperative Nationalism,' Journal of Southeast Asian Studies 3, no. 1 (1972): 262-276. 
(Eurasian) descent. As Jennifer Foray has argued, the Indonesian NSB - a thoroughly pro-colonial organization - had little in common with fascism in the sense of 'palingenetic ultra-nationalism, ${ }^{10}$ but it was rather geared towards the preservation of the colonial status quo. ${ }^{11}$ Yet, the engagement of Indonesians with Fascism and National Socialism as part of their nationalist activism has been almost entirely neglected.

Indonesia, however, is not an isolated case. For a long time, fascism has been predominantly studied as part of the history of interwar Europe. Stein Ugelvik Larsen's edited volume Fascism Outside Europe marked the beginning of an intensified preoccupation with non-European fascist movements, ${ }^{12}$ and the field of fascist studies became increasingly de-centered as a result of approaching it 'from the margins. ${ }^{13}$ In recent years, the case of the Indian Hindutva movement has garnered much attention, since it provides a prime example of a non-European ethnic ultra-nationalism obviously inspired by Italian Fascism and German National Socialism. ${ }^{14}$ 'Arab fascism' and its entanglements with fascist regimes in Europe have been subjected to closer scrutiny as well. However, the scholarly debates about fascism in the Islamic world serve as a particularly poignant reminder that notions of generic fascism, if taken too far, can result in bizarre paradigms such as Islamofascism. The latter term suggests an inherent ideological kinship between Islam and fascism, thereby trying to explain the former's alleged receptiveness towards fascist ideas. This argument can only be defended by using ahistorical, grossly reductionist and essentialist notions of both fascism and Islam. ${ }^{15}$

$10 \quad$ Roger Griffin, The Nature of Fascism (London: Routledge, 1991), 44.

11 Jennifer L. Foray, 'An Old Empire in a New Order: The Global Designs of the Dutch Nazi Party, 1931-1942,' European History Quarterly 43, no. 1 (2013): 27-52; see also Tessel Pollmann, 'Either one is a Fascist or one is not: The Indies' National-Socialist movement, the Imperial Dream, and Mussert's Colonial Milch Cow,' transl. by Benedict Anderson, Indonesia 92 (October 2011): 43-58.

12 Stein Ugelvik Larsen, ed., Fascism Outside Europe: The European Impulse against Domestic Conditions in the Diffusion of Global Fascism (New York: Columbia University Press, 2001).

13 See Roger Griffin, 'Decentering Comparative Fascist Studies,' Fascism:Journal of Comparative Fascist Studies 4(2015):103-118, accessed March 22, 2018, doi:10.1163/22116257-00402003.

14 See among others Ali Raza and Franziska Roy, 'Paramilitary Organizations in Interwar India,' South Asia 38, no. 4 (2015): 671-689; Maria Framke, Delhi-Rom-Berlin:Die indische Wahrnehmung von Faschismus und Nationalsozialismus 1922-1939 (Darmstadt: WBG, 2013); Benjamin Zachariah, 'Rethinking (the Absence of) Fascism in India, c. 1922-45' in Cosmopolitan Thought Zones: South Asia and the Global Circulation of Ideas, ed. Sugata Bose and Kris Manjapra (Basingstoke: Palgrave Macmillan, 2010), 178-209.

15 For a sober and critical perspective on Islamofascism, see Peter Wien, 'Arabs and Fascism: Empirical and Theoretical Perspectives,' Die Welt des Islams $5^{2}$ (2012): 331-350. 
This article sets out to finally make Indonesia part of this 'global turn' in the field of fascist studies. Looking at Parindra, a so-called 'cooperating' or 'cooperative' nationalist party that emerged as one of the most influential political organizations in 1935, I will show how elements of fascist-style mobilization were firmly integrated into the party's everyday activities. After the non-cooperating movement led by Sukarno had been swept away by the colonial authorities in 1934, cooperation with the Dutch was the only option left to advance the cause of Indonesian nationhood. The distinction between 'cooperators' and 'non-cooperators,' which goes back to the colonial period itself, should be approached with great care by historians. Above all, 'cooperation' meant the acceptance of the Colonial Council, the Volksraad, as the main political platform, even though this council had a purely advisory function in the colonial administration. Moreover, a party was deemed 'cooperative' by the colonial state as long as it refrained from making open demands for independence (kemerdekaan). However, the example of Parindra, traditionally seen as the exemplary cooperating party during the period this article is concerned with (1935-1942), serves as a useful reminder to take these colonial categories with a grain of salt. As continuous press censorship and tight surveillance created an ambiance of frustration, leading Parindrists turned to a rhetoric of glory and splendor, became particularly inspired by the example of German National Socialism, and tried to forge their youth organization Surya Wirawan [Sun of Heroes] into a cadre based on martial values.

Once the Japanese occupied Indonesia in 1942, romantic ideas about a society based on military values may have acquired a stale flavor for some nationalists, as their organizations were either banned or absorbed into the Japanese military administration. ${ }^{16}$ However, Japan's militaristic propaganda was, overall, a great success, especially among young Indonesians. It goes without saying that Japan's intense indoctrination campaigns sparked a passion for armed resistance that extended deep into the decolonization war between 1945 and 1949, or even beyond. And yet, leading scholars like Benedict Anderson and Robert Cribb failed to see that paramilitarism was not merely a 'child' of the Japanese occupation. While the arrival of the Japanese marked a dramatic break for Indonesian nationalism, it was not as much of a turning

16 For the most concise and up-to-date overview of the organizations endorsed or established by the Japanese, see Robert Cribb, 'Institutions,' in The Encyclopedia of Indonesia in the Pacific War, ed. Frederick Post et al. (Leiden: Brill, 2010), 102-113; see also Shigeru Sato, War, Nationalism and Peasants: Java under Japanese Occupation 1942-1945 (St. Leonards: Allen \& Unwin, 1994). 
point as Anderson suggested in his widely known publication Java in a Time of Revolution. ${ }^{17}$

Robert Cribb's famous work Gangsters and Revolutionaries is equally oblivious of the 1930s as Anderson's account, as his argument jumps from the defeat of the communist party PKI in 1927 straight to the landing of the Japanese on Java in March 1942. ${ }^{18}$ Even though he recognizes 'traditions of unrest' linked to Batavia's (nowadays: Jakarta) urban culture and connects them to nationalism, he skips the 1930 for reasons that are not specified any further. ${ }^{19}$

Therefore, the proposed argument is based on a conscious decision to go beyond the conventional narrative of Japan as the major source of 'fascist inspiration' in Indonesia. If Japan's relationship with European fascisms can be understood as part of a transnational 'fascist effect,' as Reto Hofmann has convincingly argued, then Indonesia - like any other non-European country deserves a similar degree of scrutiny. ${ }^{20}$ Japan's impact on the militarization of Indonesian society both before and during the Japanese occupation is well established in the literature. On the other hand, the agency of Indonesians in this process is still not sufficiently explored. As this article attempts to show, Indonesian fascism was more than just a product of Japanese indoctrination.

\section{A Note on Methodology and Conceptual Debates}

This article takes a performative approach to fascism, arguing that 'doing fascism' presupposes neither a coherent ideology nor the self-labeling of political actors as fascists. If we want to study fascism as an 'effect,' approaching its history 'as that of a process, not of a clearly defined model, ${ }^{21}$ we have to move beyond notions such as 'transfer' or 'transmission' in the pursuit of a more multifocal framework. Therefore, fascism should not be understood as a form of 'contagion.' As Aristotle Kallis has pointed out, 'the "contagion metaphor" says little about the specific - and very different - reasons behind the diffusion or the wildly diverse shape of the political, ideological, and institutional hybrid

17 Benedict Anderson, Java in a Time of Revolution: Occupation and Resistance, 1944-1946 (Ithaca: Cornell University Press, 1972), particularly 30-34.

18 Robert Cribb, Gangsters and Revolutionaries: The Jakarta People's Militia and the Indonesian Revolution, 1945-1949 (North Sydney: Allen and Unwin, 1991).

19 On Jakarta's 'tradition of unrest and rebellion', see Cribb, Gangsters and Revolutionaries, 24.

20 Reto Hofmann, The Fascist Effect: Japan and Italy, 1915-1952 (Ithaca: Cornell University Press, 2015).

21 Hofmann, The Fascist Effect, 3. 
outcomes. ${ }^{22}$ Recent studies of non-European fascist movements, chief among them Maggie Clinton's study of fascism in China between 1925 and 1937, have made productive attempts to consider fascism both as an effect and a manifestation of larger global trends on a local level. ${ }^{23}$

Roger Griffin's more recent theoretical works on fascism as a form of 'modernism' have shifted the focus from ideology and culture to praxis and performance. ${ }^{24}$ Moreover, the study of fascism as a 'political religion', as it was tirelessly promoted by Emilio Gentile since the 1990s, has played a major role in encouraging a more panoramic view on fascism's extensive realm of symbols, rituals, and (political) myth-making. ${ }^{25}$ Acknowledging the value of these trends, this article zooms in on the militarization of Parindra's youth wing, Surya Wirawan. To this end, my argument draws inspiration from Sven Reichardt's comparative study of the German Storm Troopers and the Italian Blackshirts, looking at fascism as a specific form of communal interaction and enactment. ${ }^{26}$

Since Surya Wirawan portrayed itself simultaneously as a scout group and the youth wing of a political party, its status as an organization was deliberately blurred. While this 'blurriness' was typical of Indonesian youth organizations throughout the $1930 \mathrm{~s},{ }^{27}$ Surya Wirawan stood out in that it frequently transgressed the border between 'harmless' scouting and fascist-inspired paramilitarism. ${ }^{28}$ Therefore, this case study does not only add to our understanding of fascism in colonial contexts, but it also contributes to debates about fascism's relationship to youth mobilization and militarization.

22 Aristotle Kallis, "The "Fascist Effect": On the Dynamics of Political Hybridization in Inter-War Europe,' in Rethinking Fascism and Dictatorship in Europe, ed. António Costa Pinto and Aristotle Kallis (Basingstoke: Palgrave Macmillan, 2014), 22.

23 Maggie Clinton, Revolutionary Nativism: Fascism and Culture in China, 1925-1937 (Durham, NC: Duke University Press, 2017).

24 Roger Griffin, Modernism and Fascism: The Sense of a Beginning under Mussolini and Hitler (New York: Palgrave Macmillan, 2007).

25 A large number of publications - among them a couple of excellent edited volumes - has emerged from this scholarly engagement with Gentile's conceptual framework. For the sake of brevity, I only refer to Emilio Gentile, The Sacralization of Politics in Fascist Italy (Cambridge, MA: Harvard University Press, 1996).

26 Sven Reichardt, Faschistische Kampfbünde: Gewalt und Gemeinschaft im italienischen Squadrismus und in der deutschen sA (Köln: Böhlau, 2002).

27 Pujo Semedi, 'Padvinders, Pandu, Pramuka: Youth and State in the Twentieth Century Indonesia' [sic], Africa Development 26, no. 3-4 (2011): 19-38.

28 Alessio Ponzio, Shaping the New Man: Youth Training Regimes in Fascist Italy and Nazi Germany (Madison, wi: University of Wisconsin Press, 2015); George L. Mosse, The Image of Man: The Creation of Modern Masculinity (New York: Oxford University Press, 1996), 160. 


\section{Doomed to Failure? How Fascism Entered Indonesia}

In July 1933, news of a recently established fascist party named Partai Fascist Indonesia [PFI; Fascist Party of Indonesia] circulated both in the Malay- and Dutch-language press. Founded in the city of Bandung by Javanese nobleman Notonindito, who had studied economics in the Netherlands and Germany, this party's ambitions revolved around the creation a federation of independent Indonesian kingdoms. Indonesian scholar Wilson, the first author to deal with the brief history of this very short-lived phenomenon, rightly remarks that PFis alleged fascism was nothing but a label. Rather, it was Notonindito's expressed aim to revive ideas that were developed in the 1910 s by aristocratic Javanese nationalists like Soetatmo Soerjokoesoemo and Noto Soeroto, among others. $^{29}$

While this strand of nationalism represented by Javanese aristocrats undoubtedly harbored a deep distrust of democracy and everything supposedly 'Western,' their view of politics hardly qualifies as fascist since it lacks any trace of a revolutionary demeanor. ${ }^{30}$ Therefore, it is not surprising that Notonindito's attempt to breathe new life into this unabashedly elitist vision did not strike a chord with revolutionary nationalists. In fact, the criticism directed against Notonindito's project was so fierce that he denied his leading role in this 'party' (if it ever was one) and quickly disappeared from the political stage within a month. ${ }^{31}$ The Dutch-language press, on the other hand, seemed to be quite unimpressed by the emergence of his party. ${ }^{32}$ Even though the PF I went down like a lead balloon as soon as its existence was proclaimed, Wilson argues that 'Notonindito made the [nationalist] movement aware that reactionary ideas on nationalism had potential among Indonesian circles. 33

In the eyes of many nationalists, the most reactionary element of Notonindito's project must have been his anti-nationalism. Since most of them were adamant about proclaiming a united Indonesia in the form of a single nation, Notonindito's plan to restore an imagined status quo ante must have appeared truly audacious to them. The role of democracy, however, barely

29 Wilson, Orang dan Partai Nazi, 119-122.

30 See also Farabi Fakih, 'Conservative corporatist: Nationalist thoughts of aristocrats: The Ideas of Soetatmo Soeriokoesoemo and Noto Soeroto', Bijdragen tot de Taal-, Landen Volkenkunde 168, no. 4 (2012): 420-444, accessed March 22, 2018, doi:10.1163/22134379 -90003551.

31 Wilson, Orang dan Partai Nazi, 123.

32 'Fascist Indonesia: Weer wat nieuws,' De Indische Courant, 22 July 1933; 'Inheemsche Fascisten: Een gewichtig programma,' Soerabaiasch Handelsblad, 22 July 1933.

Wilson, Orang dan Partai Nazi, 123. 
occupied center stage in the critiques articulated against him. Skepticism about democracy was widespread among nationalists, and it affected the left wing as much as it shaped the conceptions of more conservative, authoritarian political actors. ${ }^{34}$ Instead, a rather 'didactic,' top-down approach to politics prevailed among the large majority of educated nationalists. Disciplining 'the people' was, therefore, a central matter of concern. Throughout his long political career, Soetomo had been a particularly ardent proponent of this didactic approach to nationalism. By introducing the notion of Indonesia Moelia [Glorious Indonesia] as an alternative to the more radical Indonesia Merdeka [Independent Indonesia], he framed the nationalist cause as a journey of spiritual development and self-assertion. As Soetomo put it:

The use of [Indonesia Moelia] is not for fear of expressing a striving for Indonesia Merdeka [independent Indonesia]. On the contrary, it signifies an intention to glorify the people materially and spiritually. In our view, independence does not guarantee the glory of a people and nation; on the other hand, national glory can only result from freedom. Thus, the aspiration toward Indonesia Moelia already embraces the concept of Indonesia Merdeka since it is impossible for a country and nation to be glorious if it is not yet free. ${ }^{35}$

This zeal to 'glorify the people,' mixed with an understanding of citizenship based on 'lofty and inescapable duties,'36 explains why Soetomo thought of Parindra as an instrument to forge a new political elite capable of defending Indonesia's national interests in the future. He generally promoted the militarization of Indonesian society as a preparation for future hardships. ${ }^{37}$

While it is safe to say that Soetomo followed news reports on international developments with great interest, his fascination for military organization was not just a by-product of following the headlines. His travelogue published under the title Poespita Mantja Nagara [Flowers from Abroad], in which he recounts his experiences during an extensive journey to Japan, India, the Near

34 Robert Elson, The Idea of Indonesia (Cambridge, uk: Cambridge University Press, 2008), 52 .

Soetomo, 'Kompetisi not kongkurensi,' in Toward a Glorious Indonesia: Reminiscences and Observations of Dr. Soetomo, ed. Paul W. van der Veur (Athens, он: Ohio University Center for International Studies, 1987), 273.

36 Soetomo, 'Preparing for Combat,' in Toward a Glorious Indonesia, 251.

37 Harry Poeze, ed., Politiek-Politioneele Overzichten van Nederlandsch-Indië: Bronnenpublikatie, Vol. 4, 1935-1941 (Leiden: KITlv Press, 1994), 'November-December 1935', 56. 
and Middle East as well as Europe, contains an entire chapter dedicated to an encounter with members of the Egyptian Blue Shirts, the paramilitary organization linked to the nationalist liberal Wafd Party. He opens the chapter stating his joy of being able to freely associate 'with groups on the left as well as the right', remarking that in Indonesia he 'can't do this, because the left wing hates me and considers me a member of the bourgeoisie while other groups call me a dangerous leftist. ${ }^{38} \mathrm{He}$ describes the Blue Shirts as 'an alert and clever political group whose members are taught military science: marching, combat, and airplane flying. ${ }^{39}$ While, generally speaking, the role of fascism in the development of Egyptian nationalism should not be unduly overstated, ${ }^{40}$ the Blue Shirts were unambiguously modeled on the Italian Blackshirts. In fact, Italians living in Egypt were among the first in that country to form a paramilitary organization directly inspired by the Fascist 'original. ${ }^{41}$

In line with research on fascism's connection to modernity, I argue that modernizers like Soetomo could not help being fascinated by fascism's promise of a flawless synthesis between modernity and tradition. This zest for all things modern was an essential feature of the Indonesian nationalist movement that can be traced back to its early days in the $1910{ }^{42}{ }^{42}$ Figures like Soetomo were grappling with the issue of modernity in a period of great uncertainty in the colony. Since Indonesian nationalist discourse in the 1930s was still extremely malleable, the lines between mere ultra-nationalism and fascism were blurred from the beginning. In a context in which even communists had to be outspoken nationalists to succeed, fascism's combination of staunch nationalism and anti-establishment rhetoric was hardly a unique selling point. However, fascism lent itself to youth mobilization like no other political program. While youth mobilization was not exclusively fascist, its 'exaltation of youth was unique, however, in that it not only made a special appeal to them but also

\footnotetext{
38 Soetomo, 'Poespita Mantja Nagara,' in Toward a Glorious Indonesia, 180.

39 Soetomo, 'Poespita Mantja Nagara,' 182.

40 See Israel Gershoni and James Jankowski, Confronting Fascism in Egypt: Dictatorship versus Democracy in the 1930s (Palo Alto: Stanford University Press, 2009).

41 See James P. Jankowski, 'The Egyptian Blue Shirts and the Egyptian Wafd, 1935-1938,' Middle Eastern Studies 6 (1970): 77-95.

42 Takashi Shiraishi, An Age in Motion: Popular Radicalism in Java 1912-1926 (New York: Cornell University Press, 1990); on the nexus between modernity, nationalism, and citizenship see also Henk Schulte Nordholt, 'Modernity and Cultural Citizenship in the Netherlands Indies: An Illustrated Hypothesis,' Journal of Southeast Asian Studies 42, no. 3 (2011): 435-457; the centrality of 'Europeanness' as a multi-layered cultural ideal is thoroughly explored in Bart Luttikhuis, Negotiating Modernity: Europeanness in late colonial Indonesia, 1910-1942 (PhD diss., European University Institute, 2014).
} 
exalted youth over all other generations, without exception, and to a greater degree than any other force based itself on generational conflict.'43 Still, it is important to add that the idealization of youth was not only central to fascism but nationalism in general. Although it is disputable whether youth was a core element of European nationalism, anticolonial nationalism glorified youth for concrete historical reasons. As Benedict Anderson remarks in Imagined Communities:

It is perfectly true that in one sense Europe had been there before - if we think of Young Ireland, Young Italy, and the like. But in Europe 'young' had little in the way of definable sociological contours. One could be middle aged and still part of Young Ireland; one could be illiterate and still part of Young Italy.... In the colonies things were very different. Youth meant, above all, the first generation in any significant numbers to have acquired a European education, marking them off linguistically and culturally from their parents' generation, as well from the vast bulk of their colonized agemates. ${ }^{44}$

The promise of a new beginning as a unified nation with a single language (Bahasa Indonesia) that transcends ethnic boundaries was thus seen as inherent to youth. This transformative potential was both an idealization and at the same time a manifest social dynamic to be reckoned with. The idea of a single Indonesian nation and people was promoted by Indonesian youth organizations, particularly in the late 1920s. In 1928, the second Indonesian Youth Congress crafted the slogan 'one motherland, one nation, one language' and adopted 'Indonesia Raya' [Great Indonesia] as the national anthem. Ever since, the Pemuda [Youth] myth has been a constant companion of Indonesian history up to this day. Concerning the colonial situation, John Ingleson states that the symbols and rituals that took shape in the context of the youth movement 'played a vital part in maintaining enthusiasm, especially in times when the harsh reality of the colonial political situation threatened to induce despair and inertia.45

After the activities of the openly anticolonial Partai Nasional Indonesia (PNI), which spearheaded the nationalist movement under the leadership of Indonesia's future president Sukarno, were brought to a screeching halt

\footnotetext{
43 Stanley Payne, A History of Fascism, 1914-1945 (London: Routledge, 1995), 13.

44 Benedict Anderson, Imagined Communities: Reflections on the Origin and Spread of Nationalism, rev. ed. (London: Verso, 1983/2006), 119.

45 Ingleson, Road to Exile, 67.
} 
by the colonial government in 1934, the spirit of the youth movement was dampened, too. From 1934 onwards, only cooperating nationalist movements could openly operate in Indonesia, and even then, their scope for action was severely curtailed by the Dutch authorities. Parindra and the more left-wing Gerindo [Gerakan Rakyat Indonesia; Indonesian People's Movement] tried to advance the nationalist cause under these hostile conditions, and it is within this context that we have to examine Parindra and its youth organization Surya Wirawan as they experimented with new means to keep the idea of Indonesia alive during that period.

\section{Staged Glory: Parindra, Surya Wirawan, and the 'Fascist Halo'}

In October 1936, soon after Parindra was founded, Soetomo called for the transformation of Parindra's scout unit Surya Wirawan into an organization modeled on paramilitary groups like the NSB's Nationale Jeugdstorm [National Youth Storm] ${ }^{46}$ From 1937 onwards, the 'scouts' of Surya Wirawan were a regular sight at Parindra meetings and conferences, raising their flag, ${ }^{47}$ singing the 'Indonesia Raya' and even forming honor guards for important Parindrists (Figure 1). They quickly became an important part of the party's public presence and were soon referred to as an important 'foundation' for Parindra's political activism. ${ }^{48}$ The colonial police authorities regularly disbanded Surya Wirawan's public marches and meetings, very much to the party leadership's chagrin. As early as October 1937, the organizational obstacles faced by Surya Wirawan became a frequent matter of discussion during party meetings. ${ }^{49}$ Consequently, leading Parindrists used the Volksraad as a platform to demand a greater range of action for their youth organization in public. For instance, in 1939 Soekardjo Wirjopranoto voiced serious complaints about the way in which police regulations sabotaged the organization's activities. He made his point unmistakably clear, saying that 'if the police regulations have to be followed, this organization will not be able to survive.50

$46 \quad$ Soeara Parindra 1, October 1936, 9.

47 The party's flag was treated like an object of devotion and a 'banner.' See R.Z.A. Wantjik, 'Rantjangan Lagoe Surya Wirawan,' Soeara Parindra 3, no. 6 (1938): 238; Soeara Parindra 4, no. 2 (1939): 71.

48 Overzicht van de Inlandsche en Maleisch-Chineesche Pers [henceforth: IPO] 41, October 9 1937,672 .

49 IPO 43, 23 October 1937, 696.

50 Volksraad Handelingen 1939-40, 37ste Vergadering, 22 August 1939, 1124. 
From 1938 onward, the headquarters of Surya Wirawan officially turned the organization into a 'youth corps' and set up a separate scout group for youngsters. From then on, only men aged eighteen or older could join the organization. The expressed goal was that members of Surya Wirawan should join Parindra 'as soon as possible.51 In 1939, these instructions were specified further: Surya Wirawan was allowed to set up 'scout' groups linked to the organization. However, members below eighteen years of age were not allowed to join official political gatherings. Adult members of the political youth corps, on the other hand, were obliged to join the party within three years. Hence, Surya Wirawan was fully integrated into the party's recruitment scheme. ${ }^{52}$

As soon as the prospect of war with Japan could no longer be ignored, the colonial government started to arrange preparations and precautions. During that process, Surya Wirawan seized opportunities to get access to any form of training that was even remotely military in nature. For example, in late 1939, members of Batavia's Surya Wirawan joined a voluntary course on air raid precautions. For the colonial government, relying on Indonesian volunteers was a double-edged sword. While the Dutch authorities were in dire need of 'native' propagandists and manpower to put their defense plans into action, they were at the same time painfully aware that not all volunteers were to be trusted. The precariousness of this situation is reflected in the source material, which shows that the Dutch were unable to reconcile their need for hands-on support with their concerns over opportunists who might abuse their positions for subversive acts.

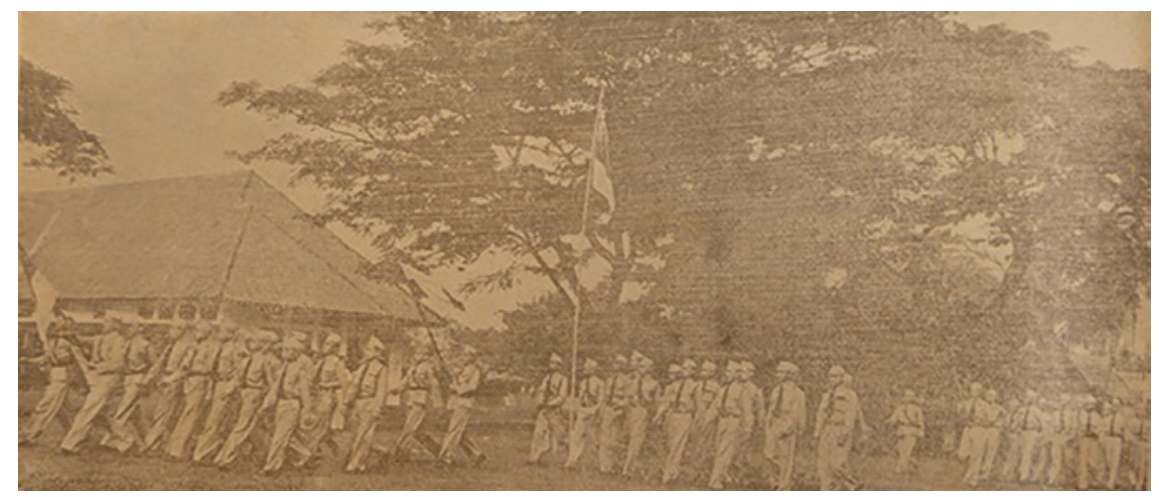

FIGURE 1 Surya Wirawan division marching through Batavia (nowadays:Jakarta), 1939. SOURCE: SOEARA PARINDRA 4, NO. 7-8 (1939).

$5^{1} \quad$ IPO 42, 15 October 1938, 694 .

$5^{2} \quad$ IPO 2, 14 January 1939, 27. 
On the one hand, leading personnel in the Luchtbeschermingsdienst [Air Raid Precaution Service] praised the support of scout organizations, civilians, and the Indonesian Press. ${ }^{53}$ On the other hand, however, Dutch authorities refused to give Indonesians access to top-positions on dubious grounds. In 1938, the director of the Binnenlandsch Bestuur [the administrative body for domestic affairs] contacted the governors of East and Central Java, among others, to enquire about two candidates that had been recommended to him. The Governor of Central Java advised the director of the Binnenlandsch Bestuur not to appoint a certain Raden Suwarjo Tirtosupono as the chief inspector of the Luchtbeschermingsdienst. In the words of the Governor, Tirtosupono's 'unsteady past and his apparently wavering character' made him an unsuitable candidate for this task. However, it seems as if this assessment of his personality was first and foremost based on his former involvement with left-leaning nationalist parties. ${ }^{54}$

The other Indonesian candidate, who was, like Tirtosupono, a civil servant by profession, was declined for the reason that his superior, the Governor of East Java, was opposed to a 'weakening of the administrative staff' by letting go of this 'excellent' employee. ${ }^{55}$ This civil servant, Raden Rooslan Wongsokoesomo, was an influential Parindrist. Yet, the document does not make any references to Wongsokoesomo's political affiliations. Rooslan Wongsokoesomo was said to have valuable organizational skills and prior experience with air raid precautions. His work as assistant-wedana (a member of the regional administrative bureaucracy) and his role as the secretary of Parindra's central administration explain why he was considered to be a gifted organizer. His prior experience with recruiting volunteers for air raid precaution measures, however, derived from his position as the head of Surya Wirawan's central organization. From that viewpoint, he must have been an ideal candidate thanks to his expertise and his networks. Nevertheless, he was not hired for the position.

This situation is characteristic of the friction between pragmatic considerations and fears of a loss of control that dominated Dutch thinking in the prewar period. In this uneasy atmosphere, parts of the public and the colonial administration slowly came to the conviction that Surya Wirawan was not an organization to be trusted. The organization's public appearance, for example, aroused suspicions. Admonishments by government authorities ensued M.H. du Croo aan Resident te Batavia, 25 Februari 1938; ANRI, Arsip BB, 3886, Nota aan Directeur van Bв; ANRI, Arsip в в 3960, Directeur в в aan Governeur van Oost-Java. 


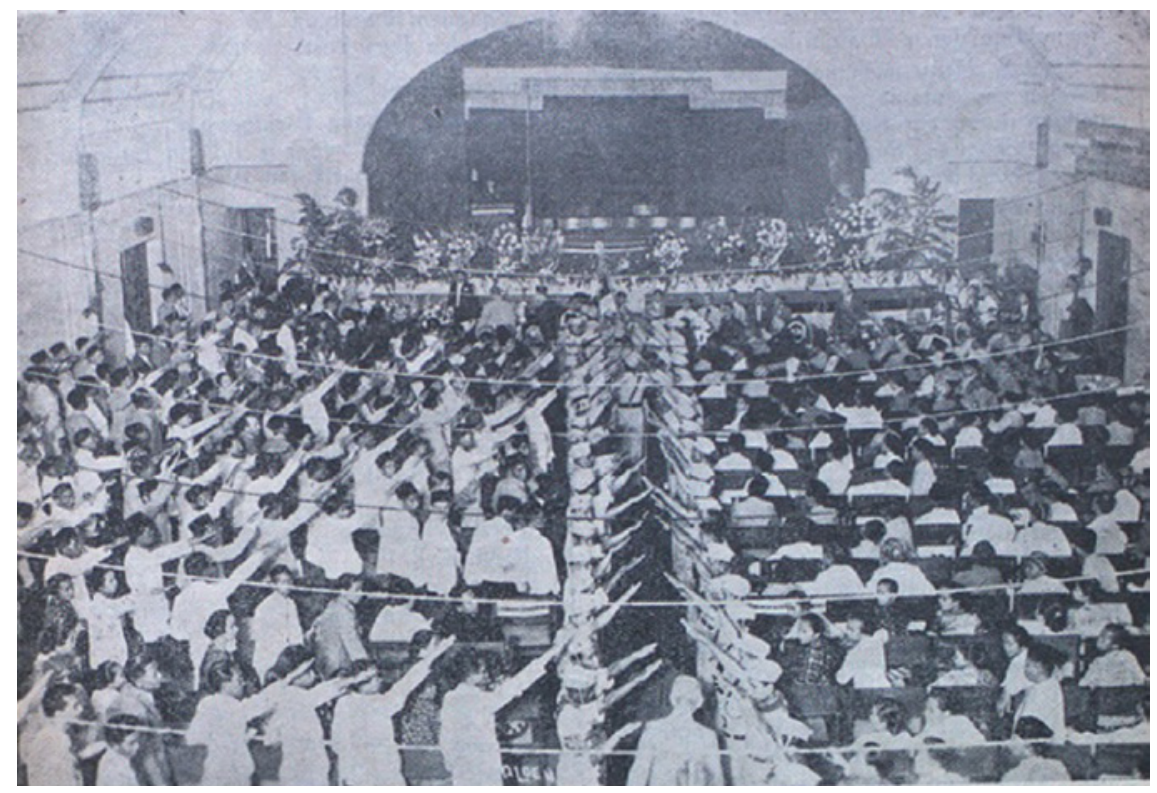

FIGURE 2 Second party congress of Partai Indonesia Raya, Bandung, 1939. SOURCE: SOEARA PARINDRA 4, NO. 1 (1939).

because 'Wirawans,' as the members of Surya Wirawan were often called, regularly showed up in uniform. When some of the organization's members applied for military training under a KNIL [Koninklijk Nederlandsch-Indisch Leger; Royal Netherlands East Indies Army] officer, they were forbidden to wear their uniforms in advance of the event. This caused great indignation in Parindra circles since it was argued that the uniform was an essential part of Surya Wirawan's self-conception. ${ }^{56}$ Moreover, this issue was problematic since the ban on wearing uniforms for volunteer work did apparently not apply for every party. As a consequence, Parindrists like Thamrin were indignant at this application of double standards. ${ }^{57}$

While these loudly voiced complaints were obviously more symptomatic of late colonial Indonesia's hyped-up news coverage, this is the right point to tell the story of a man who referred to his uniform while delivering a telltale anecdote. During a Parindra conference in Cirebon (North Java), a Parindrist named Soedarjo Tjokrosisworo gave a talk about the role of Surya Wirawan. He used this opportunity to point to his new white uniform, which, according to reactions from his fellow party members, made him look very similar to

$56 \quad$ IPO 39, 3 o September 1939, 689 .

57 See for example 'Luchtbeschermers zijn niet laks: Maar het publiek is veel te onverschillig,' Bataviaasch Nieuwsblad, 28 February 1940. 
Italian Foreign Minister Galeazzo Ciano. He then claimed to have answered as follows: 'That is perfectly possible. Once Indonesia has a parliament, I will be Count Ciano. ${ }^{58}$ As a consequence, the conference was disbanded by the police.

Tjokrosisworo was not a fringe figure, but an important voice in Parindra circles. Moreover, as the vice-chairman of the Indonesian journalists' association Perdi [Persatuan Djurnalis Indonesia; Association of Indonesian Journalists], he was an influential public figure. In an article he wrote for the pro-Parindrist newspaper Soeara Oemoem, he criticizes fellow nationalists for their lack of 'strength of character,' urging them to get inspired by Western men of 'great character' such as Tomáš Garrigue Masaryk, Aristide Briand, Hitler, and Mussolini. He complained about the unwillingness of his compatriots to absorb what he considered to be useful Western values and approaches, stating that the movement suffered from a lack of real nationalist thinkers. Quoting from one Soetomo's letters, he went on to say that Indonesians still lived in a 'period of sacrifice' which, however, would soon draw to an end. His conclusion was, therefore, optimistic, and he ended it by underpinning his appeal to his countrymen with a sentence taken from Baltus Wigersma's Het Wezen van het Fascisme (The Nature of Fascism): 'There is no people corrupt enough to be totally devoid of national feelings. ${ }^{59}$ Wigersma was a Dutch fascist theoretician who joined the NSB in the 1930 s, ${ }^{60}$ and ending an article with such a quote was anything but usual in the Indonesian nationalist press.

Tjokrosisworo's political activism was not confined to writing. As Surya Wirawan's Daerah Commissaris [Regional Commissioner] for Central Java, he coordinated activities in one of the most politically active regions of Indonesia. Moreover, he was a member of Parindra's 'Press and Propaganda Department' and gave talks about topics such as 'tactics for the political struggle. ${ }^{61}$ According to him, 'those who have the capacity to think (thinkers), should ideally only generate ideas and provide direction as well as leadership. Those who have the capacity to inspire others (propagandists) should only disseminate that which has already been created by the thinkers. And those who have the capacity to realize something (executors) are only limited by their abilities. ${ }^{62}$

The most striking feature about Parindra was that its youth organization used the Nazi salute during its meetings. Photos published in the party journal

\footnotetext{
$5^{8} \quad$ IPO 8, 24 February 1940, 131.

59 IPO 3, 16 January 1937, 38-40.

6o The book mentioned is Baltus Wigersma, Het Wezen van het Fascisme (Bussum: Van Dishoeck, 1934).

61 Soeara Parindra 4, no. 7-8 (1939).

62 'Banjak bitjara, banjak bekerdja: Politiek dan sociaal-economisch arbeid,' Soeara Parindra 6 , no. 5 (1941).
} 
Soeara Parindra show that members of Surya Wirawan used this unmistakable salute with great confidence as early as $1937,{ }^{63}$ and leading Parindrists were hardly unaware of the fact that the 'groot saluut' [great salute], or 'saluut terhormat' [most honorable salute], was used on a regular basis. ${ }^{64}$ Unfortunately, the sources do not indicate when this practice was adopted, but the visual material which is available shows that this salute was used from the upper echelons of the party to the youths of Surya Wirawan (Figure 2).

When Thamrin, the party's most vociferous and savvy spokesman, died in 1941, his funeral was staged as a display of unswerving unity. ${ }^{65}$ In Susan Abeyasekere's words, 'Thamrin's death overshadowed the details of Government charges against him. At a time when the nationalists were embittered by Government neglect and intransigence, Thamrin [who died when under forced house arrest] became a martyr. ${ }^{66}$ She then goes on to quote a Dutch observer, who describes Thamrin's funeral as a 'great mass manifestation of Indonesian nationalism, which - without any anti-Dutch words being spoken - bore a clearly anti-Dutch character. ${ }^{\prime} 7$ Through his tragic death, Thamrin truly became a martyr for Parindra's cause. In his memoirs, Jan Anne Jonkmann, president of the Volksraad from 1939 until 1942, recalls that 'Thamrin was buried like a prince. The interest and sympathy of the Indonesians were overwhelming. ${ }^{6}$

A photo taken during this public ceremony shows the party's leadership, headed by Soekardjo Wirjopranoto, marching through ranks of Surya Wirawan members performing the Nazi salute (Figure 3). Moreover, a collection of newspaper material published shortly after Thamrin's funeral provides evidence that the salute was used by 'Wirawans' and prominent Parindrists alike. ${ }^{69}$ Two years earlier, during the party's second congress in 1939, the same public ritual was performed, and it was equally impossible for it to go unnoticed by the Dutch authorities since the list of honorable guests included the Assistant-Resident of Bandung, the latter city's mayor, and - most strikingly the Adviseur voor Inlandsche Zaken [the Governor-General's advisor for 'native' affairs] G.F. Pijper. ${ }^{70}$ Pijper's report to the Governor-General, however, pays no attention to this ceremony, even though Thamrin used the congress as a

63 Soeara Parindra 2, no. 11 (1937): 179.

64 Soeara Parindra 4, no. 7-8 (1939): 227.

65 'De Begrafenis van Thamrin,' [Thamrin's funeral] De Indische Courant, 13 January 1941.

66 Susan Abeyasekere, One Hand Clapping: Indonesian Nationalists and the Dutch 1939-1942 (Clayton, Victoria: Centre of Southeast Asian Studies, Monash University, 1976), 79.

67 Jacques de Kadt, De Indonesische Tragedie (Amsterdam: Van Oorschot, 1949), 60.

68 Jan Anne Jonkman, Het Oude Nederlands-Indië (Assen: Van Gorcum, 1971), 214.

69 See Imam Soepardi, ed., Kenang-Kenangan M.H. Thamrin (Surabaya: Pustaka Nasional, 1941), 20, 29 and 37.

70

'Congres Parindra Ke II,' Soeara Parindra 4, no. 1 (1939): 3. 
platform to promote militaristic values under the premise of national defense against Japan. ${ }^{71}$

While complaints about the use of the Nazi salute were voiced in the Dutchlanguage press in reaction to the aforementioned congress, ${ }^{72}$ it was only abolished in 1941, several months after Thamrin's funeral. ${ }^{73}$ This happened as a reaction to the government banning the Nazi salute, and while Parindrists publicly admitted that they were aware of this practice being dubious, they professed they 'did not adopt it out of a particular sympathy for Hitler and his Nazis. 74 However, this ban only applied to public meetings involving non-members. Therefore the abolition of the salute was rather a lip service to ward off unwanted interventions by the colonial authorities. ${ }^{75}$

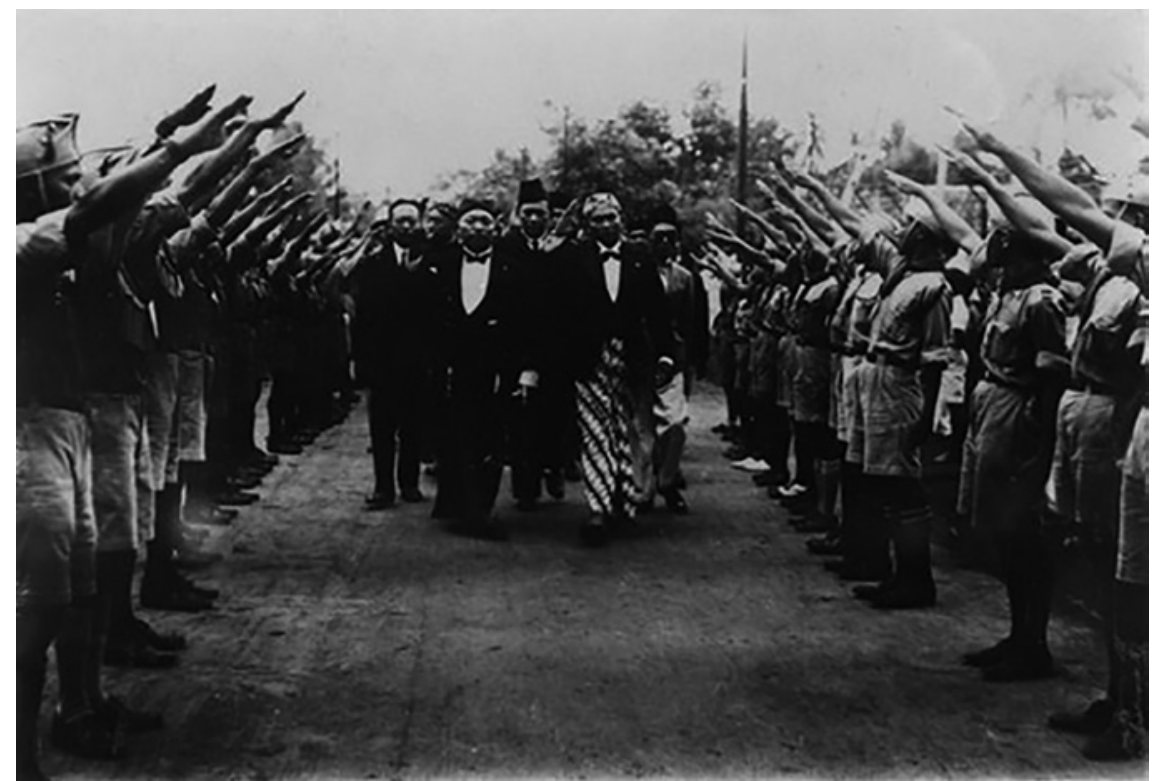

FIGURE 3 Surya Wirawan performing the 'great salute' during Thamrin's funeral, Jakarta, January 12, 1941.

SOURCE: ROYAL NETHERLANDS INSTITUTE OF SOUTHEAST ASIAN AND CARIBBEAN STUdiES (KITLV), PHOTO ARCHIVE, 33357.

71 ANRI, AR D 63a, Verslag van het tweede partijcongres van Parindra, February 10, 1939.

72 'De Parindra is democratisch: Haar Jeugorganisatie gebruikt echter een weerzinwekkende groet,' [Parindra is democratic: However, its youth organization uses a repulsive salute] Het Volksdagblad, 29 March 1939.

73 'Parindra en Hitler,' De Sumatra Post, 29 July 1941.

74 IPO 23, 7 June 1941, 855.

75 IPO 27, 5 July 1941, 983 . 
Why would the leadership of a cooperating nationalist party allow or even encourage their youth organization to show an affinity for fascism? I argue that the propaganda and public appearances of Parindra and Surya Wirawan were performances of what I would like to call 'staged glory'. It was an erratic strategy to reconcile Parindra's claim to be a party that fought for 'unity of basic principles, unity of will and thought, and [supported] interests central to the life of the nation ${ }^{16}$ with the frustrating reality of day-to-day politics in the colony. While Parindra was without a doubt the most influential cooperating party, it neither had the mass support to back up its demands nor the scope of action for concrete political decision-making. ${ }^{77}$ Since the party's representatives had chosen to operate within the narrow confines imposed by colonial rule, it was hard for them to shake off their image of being an 'elitist' party. Indeed, aristocrats and Indonesians with academic training were overrepresented in the party higher ranks. ${ }^{78}$

When the Japanese army landed on Java in May 1942, many Parindrists thought that the day of Indonesia's liberation from colonial rule had finally come. Parindra - now primarily under the leadership of former Volksraadmember Samsoedin - played an instrumental role in preparing the ground for the Japanese military administration. Surya Wirawan was renamed into Barisan Pemuda Asia Raya [Greater Asia Youth Corps] and trained to serve Japanese interests. However, Parindra's hopes were bitterly disappointed: As dissatisfaction with the former colonial cooperators grew among other parties and friction was inevitable, Japanese military authorities brushed the movement away, thus setting an abrupt end to Parindra's dominance. Instead, they decided for Sukarno and Hatta, the exiled leaders of the non-cooperating movement, to be their new collaborators of choice. ${ }^{79}$ Despite this frustrating turn of events, Parindra's leadership did not lose hope that 'their' youth would serve as an example for an independent Indonesia in the future. When the party's leadership finally announced Parindra's dissolution in February 1943 under great pressure from the Japanese, it ended this 'farewell letter' with the words:

We call upon our youth, the former Surya Wirawan members, to always keep supporting our leaders [the Japanese]. In these times, the YOUTH will determine the history of our country. It is the duty of the young generation to realize the ideals of Dr. Soetomo, namely, a glorious Indonesia. With the good opportunity that has been given to us by the Japanese

\footnotetext{
76 Soehoenan Harahap, Parindra dan Masyarakat (Surabaya: Poestaka Nasional, 1939), 9.

77 Abeyasekere, Relations, 128.

78 Ibid., 129.

79 A concise overview is provided in Sato, War, Nationalism and Peasants, $36-53$.
} 
Government and an ongoing sense of enthusiasm as our guideline, we believe that our youth will not disappoint the hopes of the people. ${ }^{80}$

When Parindra declared its farewell, Surya Wirawan was absorbed into a new, more militaristic apparatus. Parindra's party-cadre, which started out as an experiment with youth mobilization and fascist-style organization, had originally been created to fight for a 'glorious Indonesia.' As these hopes were shattered, all that remained was a semi-militarized youth organization, ready to be put to the service of the Japanese military administration. Surya Wirawan, which had been created by Parindra to prepare youth for the day of independence and national self-assertion, became the instrument of yet another foreign oppressor.

\section{Conclusion}

In Soetomo's opening speech that he gave during the first Parindra Congress in May 1937, he defined the party as 'a catalyst, or a booster that will accelerate the development and progress of the nation.' 81 This is the typical tone of the modernizer. Shortly after, however, he evoked a sense of cultural essentialism when he described the party's main aim as ensuring the 'optimal realization of [the nation's] own character and spirit.' 82 As described above, Soetomo was constantly oscillating between these two opposites, for he was an avid modernizer and a staunch traditionalist.

This paradox is something Soetomo shared with many fascist ideologues and sympathizers all over the globe. On the one hand, he envisioned the creation of a society as perfectly and expertly orchestrated as a Javanese Gamelan orchestra. On the other hand, he felt that handling political matters with kid gloves was anathema to social change. In short: Soetomo was longing for iconoclasm, but he wanted the sociocultural edifice of (invented) Indonesian tradition to emerge from this destructive process unscathed, or even reinvigorated.

Surya Wirawan was called into life as an organization designed to render this ambition visible in the public sphere and to create an aura of dynamism and power to compensate for Parindra's lack of real political power. In that

\footnotetext{
8o 'Afscheidswoord van het Hoofdbestuur van de Parindra', introd. by Bob Hering, Kabar Seberang 23 (1992), 68.

81 'Pidato Ketoea Dr. Soetomo dalam openbare receptie pemboekaan congress Parindra ke-1,' Soeara Parindra 2, no. 5 (1937): 10.

82

Ibid.
} 
sense, Indonesian fascism - like fascism anywhere else - was a symptom of nationalism in crisis. Since the Dutch authorities had effectively banned any expression of open defiance, Parindra explored the 'fascist repertoire' as a more subversive strategy. ${ }^{83}$ For this end, they did not only engage with the fascist-inspired ideas developed in imperial Japan - they drew ideas and parts of their symbolism and aesthetics from European fascism, too. The history of this interaction deserves further scrutiny.

83 On the notion of the 'fascist repertoire', see Benjamin Zachariah, 'A Voluntary Gleichschaltung? Perspectives from India towards a non-Eurocentric Understanding of Fascism,' Transcultural Studies 2 (2014), 67. 